\title{
PERAN BRAND TRUST MEMEDIASI PENGARUH BRAND IMAGE TERHADAP BRAND LOYALTY
}

\section{Wayan Govinda Gotama Putra ${ }^{1}$ Eka Sulistyawati}

\author{
${ }^{1,2}$ Fakultas Ekonomi dan Bisnis Universitas Udayana, Bali, Indonesia \\ e-mail: govindagotamap@yahoo.com
}

\begin{abstract}
ABSTRAK
Penelitian ini dilakukan dengan tujuan mengukur dan menguji pengaruh brand image terhadap brand loyalty dengan brand trust sebagai pemediasi. Seratus pemain bulutangkis yang menggunakan shuttlecock Pastra dijadikan sebagai sampel, metode yang digunakan ialah purposive sampling. Penelitian dilaksanakan di Kota Denpasar dan menyebarkan kuesioner kepada calon responden sebanyak 100 orang terpilih melalui teknik purposive sampling. Teknik analisis jalur serta uji sobel dogunakan untuk menganalisis data. Setelah diteliti didapatkan hasil bahwa variabel brand image berpengaruh secara positif dan juga signifikan terhadap variable brand trust, variabel brand image berpengaruh secara positif serta signifikan terhadap variabel brand loyalty, variabel brand trust berpengaruh secara positif yang juga signifikan terhadap variabel brand loyalty dan variabel brand trust mampu menjadi pemediasi pengaruh brand image terhadap variable brand loyalty shuttlecock Pastra.
\end{abstract}

Kata kunci: brand image, shuttlecock, brand loyalty, Pastra, brand trust

\section{ABSTRACT}

This research was conducted with the aim of measuring and testing the effect of brand image on brand loyalty with brand trust as a mediator. One hundred badminton players using Shuttlecock Pastra were used as samples, the method used was purposive sampling. The study was conducted in Denpasar City and distributed questionnaires to prospective respondents as many as 100 people selected through a purposive sampling technique. Path analysis techniques and sobel tests are used to analyze data. After investigating, it was found that brand image variables had a positive and significant effect on brand trust variables, brand image variables had a positive and significant effect on brand loyalty variables, brand trust variables had a positive effect that was also significant for brand loyalty variables and brand trust variables were able to mediate the influence of brand image on brand loyalty shuttlecock Pastra.

Keywords: brand image, shutllecock, brand trust, Pastra, brand loyalty 


\section{PENDAHULUAN}

Salah satu olahraga yang mudah murah dan banyak digemari masyarakat di kota Denpasar adalah Bulutangkis. Permainan Bulutangkis adalah olahraga yang dimana dua orang saling berlawanan untuk permainan single dan empat orang saling berlawanan untuk permainan double, dengan sebuah raket sebagai alat untuk memukul shuttlecock. Bulutangkis merupakan olahraga yang cukup mudah dengan cara memukul bola melewati net (jaring pembatas dalam permainan bulutangkis) ke arah bidang permainan lawan.

Olahraga lapangan seperti bulutangkis, sepak bola, tenis meja, voli, dan tenis menggunakan bola dalam permainannya. Kebanyakan olahraga ini, seperti sepak bola, basket, tenis meja, voli, tenis menggunakan bola yang berbentuk bundar, sedangkan dalam permainan bulutangkis menggunakan bola untuk yang berbentuk kerucut. Nama bola dalam permainan bulutangkis adalah shuttlecock. Shuttlecock pada awalnya berbahan dasar bulu ayam, oleh karenanya bola bulutangkis disebut dengan shuttlecock. Perkembangan teknologi pada dunia bulutangkis, shuttlecock berbahan dasar bulu ayam mulai ditinggalkan, ini disebabkan oleh adanya bahan dasar yang lebih baik untuk shuttlecock yaitu bulu angsa. Shuttlecock dengan bahan dasar bulu angsa terbang dengan kecepatan yang lebih stabil dibandingkan bahan dasar bulu ayam.

Kebutuhan pemain bulutangkis akan produk shuttlecock, khususnya di kota Denpasar sangat tinggi. Tingginya permintaan shuttlecock bulutangkis di Kota Denpasar membuat banyak perusahaan shuttlecock meluncurkan produk mereka ke kota Denpasar, diantaranya ada shuttlecock merek Pastra, Saxon, Surya Jaya, 
Nasional, Expass. Diantara banyak merek shuttlecock yang ada di Kota Denpasar salah satu shuttlecock yang paling populer adalah shuttlecock merek Pastra. Ini ditunjukan berdasarkan hasil prasurvei yang dilakukan pada tahun 2018 kepada 30 responden.

Tabel 1.

Hasil Pra-Survei Bauran Pemasaran shuttlecock Pastra di Kota Denpasar Tahun 2018.

\begin{tabular}{clccc}
\hline No & Pertanyaan & \multicolumn{2}{c}{ Jawaban } & \multirow{2}{*}{ Responden } \\
\cline { 3 - 4 } & & Ya & Tidak & \\
\hline 1 & $\begin{array}{l}\text { Saya merasa shuttlecock } \\
\text { Pastra merupakan produk } \\
\text { yang populer }\end{array}$ & 30 & 0 & 30 \\
2 & $\begin{array}{l}\text { Saya merasa harga } \\
\text { shuttlecock Pastra sesuai } \\
\text { dengan kualitas yang } \\
\text { diberikan }\end{array}$ & 30 & 0 & 30 \\
$3 \quad \begin{array}{l}\text { Saya merasa mudah untuk } \\
\text { mengakses (membeli) } \\
\text { shuttlecock Pastra }\end{array}$ & 27 & 3 & 30 \\
$\begin{array}{l}\text { Menurut saya promosi yang } \\
\text { dilakukan shuttlecock Pastra } \\
\text { menarik saya untuk membeli } \\
\text { shuttlecock Pastra }\end{array}$ & 15 & 15 & 30 \\
\hline Sumber: Pra-survei tahun 2018 & & & \\
\hline
\end{tabular}

Dalam dunia persaingan saat ini, konsumen dihadapkan pada banyak suara dan gambar di majalah, Koran, baliho, situs web, radio dan televisi (Bimal, Dhanda, \& Nagra, 2012). Berdasarkan hal tersebut, perlu diadakan pra-survei dan wewancara untuk mengetahui, produk shuttlecock yang paling populer dan digemari diantara banyak produk lainnya di Kota Denpasar. Perusahaan yang secara brand produknya lebih dikenal serta baik secara publik, tentunya akan memiliki tempat yang baik di pasar dan akan mampu mempertahankan keunggukan kompetitifnya serta dapat meningkatkan nilai dari pangsa pasar (Shahroudi \& Naimi, 2014). 
Pastra merupakan salah satu merek shuttlecock bulutangkis yang berasal dari Indonesia dan telah memasuki kota Denpasar sejak tahun 2008. Kelebihan yang dimiliki shuttlecock Pastra dibanding pesaingnya ada pada kualitasnya yang baik dan daya tahan shuttlecock yang kuat. Keunggulan ini menjadi daya tarik konsumen dan loyal kepada merek Pastra.

Berdasarkan hasil wewancara yang telah dilakukan ke lima toko olahraga yang ada di Kota di Denpasar, didapatkan hasil penjualan shuttlecock bulutangkis dalam satu minggu sebagai berikut. Pada toko Govinda Sport, shuttlecock Pastra dapat terjual 500-750 slop, sedangkan shuttlecock Saxon dapat terjual 200-250 slop, dan shuttlecock Surya Jaya terjual dapat 100-150 slop. Sedangkan pada Sidharta Sport shuttlecock Pastra dapat terjual 75-100 slop, sedangkan shuttlecock Saxon dapat terjual 35-50 slop. Pada Seraya Sport Centre, shuttlecock Pastra terjual 50-75 dalam satu minggu sedangkan shuttlecock Saxon terjual 3050 slop. Pada Nandya Health Centre shuttlecock Pastra terjual 50-60 slop, Saxon 30-40 slop dan Surya Jaya 5-10 slop. Gelogor Carik Badminton shuttlecock Pastra terjual 50-75 slop dan shuttlecock Saxon 35-50 slop. Dari hasil wewancara yang telah dilakukan kepada pemilik 5 toko olahraga yang ada di Kota Denpasar, dapat disimpulkan shuttlecock Pastra merupakan shuttlecock yang paling digemari pemain bulutangkis di Kota Denpasar untuk saat ini.

Loyalitas merek (brand loyalty) menurut Chandio et al. (2015) adalah suatu alat untuk menentukan bertahannya sebuah perusahaan didalam persaingan. Brand loyalty atau loyalitas merek dengan kata lain dapat menentukan suatu 
perusahaan atau produk untuk berkembang dan dapat bersaing dengan perusahaan lain atau malah tertinggal dan kalah dari produk pesaing.

Brand image adalah keyakinan, persepsi serta ingatan pertama kali, disaat mendengar slogan merek, serta terus ada dibenak konsumen. Kotler dan Keller (2009). Kemudian menurut (Venessa \& Arifin, 2017) citra merek atau brand image merupakan asosiasi yang berada di benak pelanggan untuk menjadi perbedaan diantara merek lainnya misalnya, desain huruf, warna maupun lambang. Perkembangan zaman saat ini, aspek pemasaran tidak hanya ditentukan kepada fugnsi produk semata, akan tetapi akan lebih berfokus pada pertempuran brand image (Hayat, Ghayyur, \& Siddique, 2013). Jika brand image dapat memenuhi harapan dari konsumen atau bisa memberikan lebih dari harapan konsumen, serta dapat memberi jaminan kualitask kepada setiap kesempatan penggunaannya, ditambah lagi jika brand image tersebut diproduksi oleh perusahaan yang mempunyai reputasi, maka konsumen akan bertambah yakin dengan pilihannya dan konsumen akan oercaya pada brand image, menyukai brand image, dan menganggap brand image tersebut bagian dari dirinya (Zafar \& Rafique, 2010). Brand image yang terpercaya dan baik akan memberikan rasa aman didalam diri konsumen, kemudia akan membuat konsumen tertarik melakukan pembelian pada produk yang ditawarkan brand tersebut (Pechyiam \& Jaroenwanit, 2014). Tanpa brand image yang positif dan kuat, sulit untuk perusahaan menarik pelanggan baru dan mempertahankan brand trust konsumen (Sivesan, 2013). Cara untuk menarik pelanggan baru dan mempertahankan yang sudah ada, brand image sangat penting karena faktanya konsumen selalu mencari 
produk dan layanan yang memiliki citra merek yang baik (Neupane, 2015). Brand trust memberikan pengaruh terhadap keberlangsungan sebuah merek, karena merek akan mampu berkembang di pasar ketika merek tersebut mendapatkan kepercayaan dari konsumen (Hidayah, 2016). Brand trust menentukan pembelian konsumen terhadap suatu merek, kepercayaan mempunyai potensi untuk menciptakan hubungan-hubungan yang bernilai tinggi. Banyaknya berbagai macam produk yang muncul dengan kualitas produk yang sudah memiliki standar, dengan mudah dapat ditiru dan dimiliki oleh siapapun, menyebabkan perusahaan sulit untuk bertahan sebagai pemimpin pasar (Sabunwala, 2013). Brand trust akan mendorong perilaku pembelian ulang dan loyalitas terhadap sebuah merek. (Sari \& Widowati, 2014) memiliki pendapat brand trust ialah konsumen bersedia untuk mempercayai suatu merek dengan semua risiko yang ada karena adanya harapan dibenak konsumen bahwa mereka akan mendapatkan hasil yang baik dari suatu merek, oleh karenanya konsumen akan setia terhadap merek. Pendapat dari (Dharmayana \& Rahanatha, 2018) Kepercayaan konsumen terhadaap suatu merek begitu penting untuk perusahaan untuk menjaga serta menjalin hubungan yang baik dengan pelanggan serta kepercayaan dari pelanggan, sehingga pelanggan akan melakukan pembelian kembali produk di perusahaan, oleh karena itu produk harus dikenalkan dengan baik sehingga bias membangun kepercayaan pada diri pelanggan. Loyalitas konsumen kepada suatu merek akan meningkat jika kepercayaan konsumen terhadap merek meningkat. (Gecti \& Zengin, 2013).

Semakin banyaknya pesaing seperti, Saxon, Surya Jaya, Nasional, Esspass memberikan banyak pilihan shuttlecock bagi pemain bulutangkis di Kota 
Denpasar. Berbagai macam merek memberikan promo dan keunggulan produknya masing-masing sehinga tercipta brand image tersendiri dibenak konsumen. Berdasarkan penelitian yang telah saya lakukan di kota Denpasar tahun 2018 dengan menggunakan metode pra survei dengan cara menyebarkan kuisioner kepada tiga puluh responden, didapat hasil bahwa seluruh responden mengetahui dan sudah pernah membeli shuttlecock Pastra. Ini menunjukan bahwa shuttlecock Pastra merupakan merek yang populer di kalangan pemain bulutangkis di kota Denpasar. Enam dari tiga puluh responden menyatakan bahwa mereka membeli shuttlecock Pastra disebabkan oleh brand image shuttlecock Pastra, sedangkan empat belas responden menyatakan mereka memilih menggunakan shuttlecock Pastra tidak disebabkan oleh brand image produk ini. Hal ini menunjukan bahwa brand image shuttlecock Pastra masih dipertanyakan pengaruhnya terhadap brand loyalty shuttlecock Pastra. Dua puluh tiga dari tiga puluh responden menyatakan bahwa mereka menggunakan shuttlecock Pastra dikarenakan mereka percaya terhadap merek ini dan tujuh responden menyatakan tidak. Melihat peta persaingan shuttlecock bulutangkis sangat kompetitif di kota Denpasar, serta hasil pra-survei kepada tiga puluh orang mengenai gambaran mereka terhadap shuttlecock Pastra, ini merupakan objek yang menarik untuk diteliti.

Banyak penelitian yang telah dilakukan dimasa lalau diantaranya, (Rizan, Saidani, \& Sari, 2012) menyebutkan citra berpengaruh secara positif yang juga signifikan terhadap loyalitas merek Tea Botol Sosro. Didalam penelitian itu juga menyebutkan kepercayaan merek terhadap loyalitas merek Tea Botol Sosro secara positif dan sginfikan. Hasil penelitian yang serupa jua diperoleh dari penelitian 
yang dilakukan (Noor, 2014) yang mengemukakan bahwa brand loyalty dipengaruhi oleh brand image KingThaiTea namun tidak signifikan dan brand trust berpengaruh secara signifikan terhadap brand loyalty KingThaiTea.

Meskipun demikian, penelitian (Upamanyu \& Mathur, 2012) menemukan bahwa tidak ada pengaruh positif brand image terhadap brand loyalty. (Maliyah, 2015) didalam penelitiannya mengungkapkan hal yang berbeda dimana brand image tidak memiliki pengaruh terhadap brand trust. Hal serupa ditemukan oleh (Hadi \& Sumarto, 2010) serta (Sibagaring \& Nursanti, 2010) menyatakan bahwa variable brand loyalty tidak dipengaruhi secara positif oleh variable brand image. Penelitian (Satyadharma, 2014) menemukan hasil sejalan dimana, vairabel brand loyalty tidak dipengaruhi secara oleh variable brand image.

Berdasar dari latar belakang permasalahan, ditarik rumusan masalah sebagai berikut 1) bagaimana pengaruh brand image terhadap brand trust shuttlecock Pastra; 2) bagaimana pengaruh brand image terhadap brand loyalty shuttlecock Pastra ; 3) bagaimana pengaruh brand trust terhadap brand loyality shuttlecock Pastra; 4) bagaimana brand trust berperan sebagai pemediasi pengaruh brand image terhadap brand loyalty shuttlecock Pastra. Penelitian dilakukan dengan tujuan untuk memberikan dan memaparkan jawaban dari rumusan masalah tersebut.

Penelitian ini memiliki dua manfaat, yaitu pertama manfaat teoritis dimana hasil penelitian ini dapat menambah bukti empiris dalam manajemen pemasaran, secara khusus di dalam aspek brand image membentuk brand loyality. Serta dapat dipakai untuk acuan atau sebagai sumber informasi mengenai peran brand brand 
trust memediasi brand image. Kedua manfaat praktis, dimana nantinya hasil dari penelitian ini, bisa berguna sebagai materi evaluasi pengembangan strategi bagi U.D Pastra. Dimana hasil evaluasi ini dapat dijadikan masukan yang berguna bagi U.D Pastra didalam mempertahankan dan meningkatkan brand loyalty terhadap shuttlecock Pastra.

Menurut Kotler (2012:266) brand image adalah kepercayaan serta penglihatan yang ada di benak konsumen dan langsung terpendam serta cerminan dari asosiasi yang ada diingatan pelanggan atau konsumen tersebut. Brand trust memberikan pengaruh terhadap keberlangsungan sebuah merek, karena ketika merek telah kehilangan kepercayaan dari pelanggan maka merek tersebut tidak mudah lagi untuk berkembang di pasar, sebaliknya ketika sebuah merek mendapatkan kepercayaan dari pelanggan, merek tersebut akan terus berkembang di pasar. Aaker et al. (2007: 69) mengemukankan brand trust "Sebagai kerelaan individu mempercayai kemampuan merek untuk memuaskan kebutuhannya". Chi et al. (2009: 231) dalam (Hidayah, 2016) menyatakan brand trust artinya pelanggang-pelanggan percaya suatu merek pasti menawarkan suatu produk yang bisa bermanfaat, funsinya lengkap, keterjaminan kualitas, dana memiliki service pasca pembelian".

Brand loyalty adalah konsumen memilih untuk konsisten membeli merek yang sama, produkspesifik serta pelayanan tertentu (Schiffman dan Kanuk, 2009). Aaker (2007) berpendapat loyalitas merek memiliki definisi sebagai ukuran pelanggan antar keterkaitannya kepada sebuah brand. Gambaran tentang apakah 
pelanggan dapat beralih ke lain produk dapat dilihat dari pengukuran ini, apalagi jika ada perubahan harga atau kelengkapan atribut lainnya.

(Efendy \& Suryadinata, 2013) menyatakan didalam penelitiannya citra merek secara positif dan signifikan memiliki pengaruh terhadap brand trust. (Noor, 2014) dalam penelitian yang dilakukannya juga menyimpulkan kepercayaan merek dipengaruh secara positif dan signifikan oleh citra merek. Peneleitian mendukung dengan hasil serupa, juga terdapat pada penelitian (Alhaddad, 2015).

$\mathrm{H}_{1}$ : Brand image berpengaruh positif dan juga signifikan terhadap brand trust shuttlecock Pastra

Penelitian (Rizan et al., 2012) mengemukakan hasil, brand loyalty dari Tea Botol Sosro dipengaruhi oleh brand image secara positif serta signifikan. Penelitian dengan hasil serupa juga ditemukan oleh (Efendy \& Suryadinata, 2013) yang menyimpulkan, brand image secara positif yang jua signifikan memiliki pengaruh terhadap variabel brand loyalty. Penelitian (Chinamona, 2016) mendapatakan hasil jika brand image mempunyai pengaruh secara positif serta signifikan terhadap brand loyalty.

$\mathrm{H}_{2}$ : Brand image mempunyai pengaruh positif dan signifikan terhadap brand loyalty shuttlecock Pastra

Berdasarkan penelitian (Kusuma, 2014) disimpulkan secara positif dan signifikan brand trust berpengaruh terhadap brand loyalty. Dapat ditarik kesimpulan semakin baik brand trust yang dibentuk, dengan demikian semakin baik juga brand loyalty konsumen. (Putra \& Sulistyawati, 2014) dalam penelitiannya menemukan jika kepercayaan merek secara positif signifikan 
mempengaruhi brand loyalty telepon pintar merek Apple. Hasil penelitian serupa juga didapatkan pada penelitian (Kabadayi \& Alan, 2012).

$\mathrm{H}_{3}$ : brand trust memiliki pengaruh positif serta signifikan terhadap brand loyalty shuttlecock Pastra

Didalam penelitian (Efendy \& Suryadinata, 2013), (Rodiques \& Rahanatha, 2018) didapatkan hasil penelitian bahwa brand image (kepercayaan merek) secara positif mampu menjadi pemediasi pengaruh brand image terhadap brand loyalty. (Handayani \& Martini, 2015) juga mendapatkan hasil serupa dalam penelitiannya.

$\mathrm{H}_{4}$ : Brand trust sebagai pemediasi dari pengaruh brand image terhadap brand loyalty shuttlecock Pastra

Berdasarkan dari definisi dan kajian teori dari beberapa ahli yang telah dipaparkan, maka disusun gambar dari kerangka konseptual, sebagai berikut:

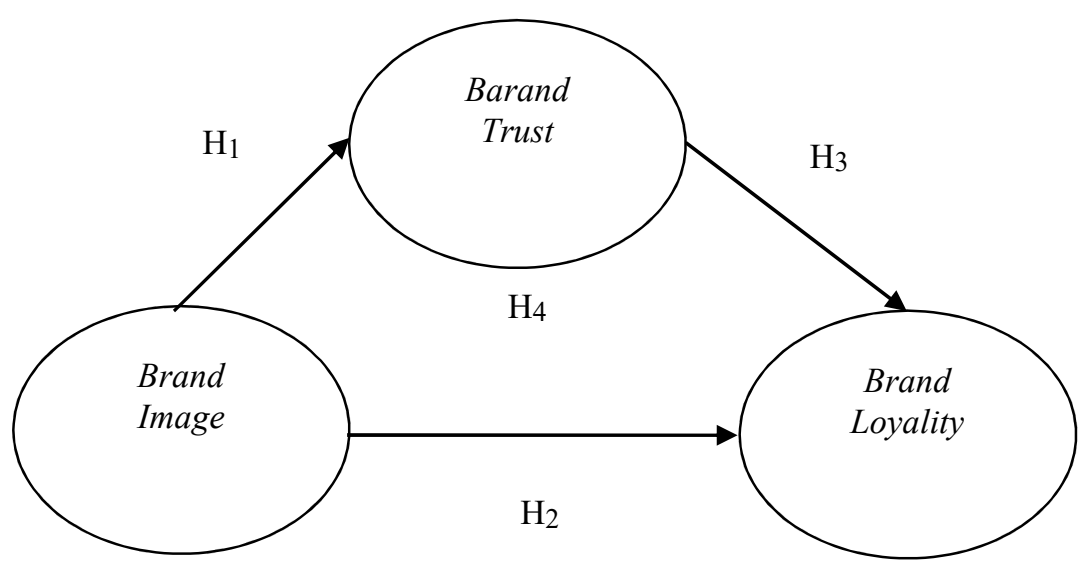

Gambar 1. Kerangka Konseptual

Sumber: Dikambangkan dari penelitian Rodiques dan Rahanata, 2018

\section{METODE PENELITIAN}

Penelitian ini adalah penelitian asosiatif yang bertujuan guna mengidentifikasi pengaruh antara variabel brand image terhadap brand trust 
melalui pemediasi variable brand loyalty shuttlecock Pastra. Penelitian dilakukan di Kota Denpasar, dikarenakan di Kota Denpasar intensitas masyarakat yang bermain bulutangkis cukup tinggi. Objek yang di teliti didalam penelitian diantarnya adalah brand image $(\mathrm{X})$ yaitu variabel eksogen, variabel pemediasi brand trust $(\mathrm{M})$ dan brand loyalty $(\mathrm{Y})$ sebagai variabel endogen. Indikator yang digunakan untuk mengukur ketiga variable tersebut akan disajikan pada table berikut.

Tabel 2.

Kisi-Kisi Instrumen Penelitian

\begin{tabular}{clll}
\hline Variabel & & \multicolumn{1}{c}{ Indikator } & \multicolumn{1}{c}{ Refrensi } \\
& a. & Functional benefit $\left(\mathrm{X}_{1}\right)$ & Keller $(1993)$ \\
dan Shimp & $(2014)$ \\
Brand & b. & Symbolic benefit $\left(\mathrm{X}_{2}\right)$ & \\
Image $(\mathrm{X})$ & c. & Experiental benefit $\left(\mathrm{X}_{3}\right)$ & \\
& d. & Favorable $\left(\mathrm{X}_{4}\right)$ & (Delgado- \\
Brand & a. & Brand reliability $\left(\mathrm{M}_{1}\right)$ & Ballester, \\
Trust & b. & Brand Characteristic $\left(\mathrm{M}_{2}\right)$ & 2003; Lau \& \\
$(\mathrm{M})$ & c. & Consumer-brand Characteristic $\left(\mathrm{M}_{3}\right)$ & Lee, 1999) \\
& & & Rangkuti \\
Brand & a. & Behavior measures $\left(\mathrm{Y}_{1}\right)$ & \\
Loyalty $(\mathrm{Y})$ & b. & Measuring satisfaction $\left(\mathrm{Y}_{2}\right)$ & \\
& c. & Measuring commitment $\left(\mathrm{Y}_{3}\right)$ &
\end{tabular}

Sumber: Penelitian Rodiques dan Rahanata, 2018

Brand image adalah apa yang ada di benak maupun pikiran konsumen ketika melihat ataupun mendengar shuttlecock Pastra. Adapun instrumen pengukuran brand image yang diadopsi dari hasil studi Keller (1993), serta diadopsi pula dari hasil studi Shimp (2014) adalah sebagai berikut : 1) Functional benefit $\left(\mathrm{X}_{1}\right)$, dimana konsumen merasa shuttlecock Pastra merupakan produk yang awet saat digunakan. 2) Symbolic benefit $\left(\mathrm{X}_{2}\right)$, dimana konsumen merasa shuttlecock Pastra merupakan shuttlecock yang premium. 3) Experiental benefit $\left(\mathrm{X}_{3}\right)$, dimana konsumen merasa saat menggunakan shuttlecock Pastra, memiliki 
kesan yang baik terhadap shuttlecock bulutangkis merek Pastra. 4) Favorable $\left(\mathrm{X}_{4}\right)$, dimana konsumen merasa bahwa shuttlecock Pastra adalah merek shuttlecock yang mudah diingat dibenak konsumen.

Brand trust adalah konsumen bersedia mempercayai shuttlecock Pastra untuk memenuhi kebutuhannya dalam melakukan permainan bulutangkis. Adapun instrument pengukuran brand trust yang diadopsi dari hasil studi (DelgadoBallester, 2003; Lau \& Lee, 1999) adalah sebagai berikut : 1) Brand reliability $\left(\mathrm{M}_{1}\right)$, dimana konsumen merasa yakin bahwa shuttlecock Pastra mampu memenuhi kebutuhan konsumen untuk bermain bulutangkis. 2) Brand Characteristic $\left(\mathrm{M}_{2}\right)$, dimana konsumen merasa shuttlecock Pastra memiliki reputasi merek yang baik dibenak konsumen. 3) Consumer-brand Characteristic $\left(\mathrm{M}_{3}\right)$, dimana konsumen merasa timbul rasa suka saat bermain bulutangkis menggunakan shuttlecock Pastra.

Brand loyalty adalah konsumen secara konsisten melakukan pembelian ulang shuttlecock Pastra. Adapun instrumen pengukuran brand loyalty yang diadopsi dari hasil studi Rangkuti (2009) adalah sebagai berikut: 1) Behavior measures $\left(\mathrm{Y}_{1}\right)$, dimana konsumen membeli shuttlecock Pastra secara berkala atau berulang. 2) Measuring satisfaction $\left(\mathrm{Y}_{2}\right)$, dimana konsumen merasa puas dengan shuttlecock Pastra. 3) Measuring commitment ( $\left.\mathrm{Y}_{3}\right)$, dimana konsumen secara sukarela untuk merekomendasikan shuttlecock Pastra kepada orang lain.

Jenis data yang dipakai didalam penelitian ini ada dua jenis, yang pertama data kualitatif, dimana data kualitatif dipenelitian ini berupa pendapat dari responden yang diuraikan didalam kuesioner. Jenis data yang kedua yaitu data 
kuantitatif, dimana didalam datan berupa hasil pengolahan kuesioner. Data penelitian bersumber pada dari dua jenis data, pertama sumber data primer, dimana data ini berupa jawaban responden mengenai indikator-indikator yang tercantum berupa pernyataan pada lembar kuesioner. Kedua, sumber data sekunder, berupa data observasi dan dokumentasi perusahaan maupun lapangan bulutangkis di Kota Denpasar.

Populasi yang diunakan adalah pengguna shuttlecock bulutangkis Pastra di Kota Denpasar, dimana jumlahnya tidak dapaet terhitung secara pasti (infinite) serta kuesioner digunakan untuk mengumpulkan data. Kuesioner disebar luaskan kepada calon responden yang sesuai dengan kriteria pengujian. Pengukuran jawaban dari responden akan diukur menggunakan Skala Likert. Kriteria responden untuk penelitian ini diantaranya responden minimal berusia 19 tahun dan telah menamatkan pendidikan SMA agar mampu memahami dan mengisi pernyataan atau pertanyaan dalam kuesioner dengan baik, responden bermain bulutangkis di Kota Denpasar, responden mengenal dan sudah pernah menggunakan shuttlecock Pastra, responden pernah menggunakan shuttlecock Pastra selama tiga bulan terakhir. Uji analisis jalur dan juga uji sobel digunakan sebagai teknik analisis data didalam penelitian.

Tabel 3. menunjukan, dari kriteria jenis kelamin, pengguna shuttlecock Pastra didominasi oleh laki-laki sebanyak $82 \%$. Untuk usia responden didominasi pada rentang 19-23 tahun yaitu sebanyak 77\%. Untuk jenjang pendidikan, responden didominasi oleh rentang pendidikan minimal SMA/sederajat sebesar 
65\%. Dalam kategori pekerjaan, responden didominasi oleh mahasiswa/pelajar sebesar $58 \%$.

\section{HASIL DAN PEMBAHASAN}

Tabel 3.

Karakteristik Responden

\begin{tabular}{|c|c|c|c|c|}
\hline Nomor & $\begin{array}{c}\text { Kriteria } \\
\text { Responden }\end{array}$ & $\begin{array}{l}\text { Klasifikasi } \\
\text { Responden }\end{array}$ & Jumlah (orang) & $\begin{array}{c}\text { Persentasi } \\
(\%)\end{array}$ \\
\hline \multirow[t]{3}{*}{1.} & Jenis Kelamin & Laki-laki & 82 & 82 \\
\hline & & Perempuan & 18 & 18 \\
\hline & & Jumlah & 100 & 100 \\
\hline \multirow[t]{5}{*}{2.} & Usia & 19-23 tahun & 77 & 77 \\
\hline & & 24-28 tahun & 15 & 15 \\
\hline & & 29-33 tahun & 1 & 1 \\
\hline & & $>33$ tahun & 7 & 7 \\
\hline & & Jumlah & 100 & 100 \\
\hline \multirow[t]{6}{*}{3.} & Pendidikan & SMA/sederajat & 65 & 65 \\
\hline & Terakhir & Diploma & 4 & 4 \\
\hline & Ditempuh & $\mathrm{S} 1$ & 25 & 25 \\
\hline & & S2 & 5 & 5 \\
\hline & & S3 & 1 & 1 \\
\hline & & Jumlah & 100 & 100 \\
\hline \multirow[t]{7}{*}{4.} & Pekerjaan & Mahasiswa/ Pelajar & 58 & 58 \\
\hline & & PNS & 6 & 6 \\
\hline & & Karyawan Swasta & 14 & 14 \\
\hline & & Wiraswasta & 13 & 13 \\
\hline & & TNI/Polri & 3 & 3 \\
\hline & & Lainnya & 6 & 6 \\
\hline & & Jumlah & 100 & 100 \\
\hline
\end{tabular}

Sumber: Data diolah, 2018

Uji validitas di dalam penelitian ini berguna untuk mengetahui serta mengukur seberapa kuat hubungan variabel dengan variabel yang lain dan mengetahui ketepatan kuesioner. Jika koefisien korelasi $(r>0,3)$, ini artinya instrumen yang digunakan didalam penelitian dikatan valid.

Hasil pengolahan data yang didapat dari Tabel 4. menujukkan seluruh indikator menunjukan nilai koefisien korelasi yang tidak lebih kecil ataupun sama 
dengan 0,3 maka dari itu instrumen yang digunakan untuk mengukur adalah indikator atau instrument valid untuk digunakan.

Tabel 4.

Uji Validitas

\begin{tabular}{cccc}
\hline \multirow{2}{*}{ No. } & Variabel & Inst. & Uji Validitas \\
\cline { 3 - 3 } & & $\mathrm{X}_{1}$ & Pearson Correlation \\
1. & Brand & $\mathrm{X}_{2}$ & 0,923 \\
& Image $(\mathrm{X})$ & $\mathrm{X}_{3}$ & 0,855 \\
& $\mathrm{X}_{4}$ & 0,911 \\
& & $\mathrm{M}_{1}$ & 0,782 \\
2. & Brand & $\mathrm{M}_{2}$ & 0,874 \\
& Trust $(\mathrm{M})$ & $\mathrm{M}_{3}$ & 0,888 \\
& & $\mathrm{Y}_{1}$ & 0,888 \\
3. & Brand & $\mathrm{Y}_{2}$ & 0,765 \\
& Loyalty $(\mathrm{Y})$ & $\mathrm{Y}_{3}$ & 0,939 \\
& & & 0,929 \\
\hline
\end{tabular}

Sumber : Data diolah, 2018

Uji Reliabilitas, instrumen dapat dikatakan reliabel jika instrumen yang bilamana dipakai sekian kali mengukur suatu objek yang sama, data yang dihasilkan akan sama, krtierinya adalah CronbachAlpha $>0,60$.

Tabel 5.

Uji Reliabilitas

\begin{tabular}{cccc}
\hline \multirow{2}{*}{ Nomor } & Variabel & Inst. & Uji Realiabilitas \\
\cline { 3 - 4 } & & $\mathrm{X}_{1}$ & Cronbach Alpha \\
\cline { 3 - 3 } 1. & & $\mathrm{X}_{2}$ & \\
& & $\mathrm{X}_{3}$ & 0,886 \\
& & $\mathrm{X}_{4}$ & \\
2. Brand Image (X) & $\mathrm{M}_{1}$ & 0,858 \\
& Brand Trust & $\mathrm{M}_{2}$ & \\
& & $\mathrm{M}_{3}$ & 0,856 \\
3. & Brand Loyalty & $\mathrm{Y}_{1}$ & \\
& $(\mathrm{Y})$ & $\mathrm{Y}_{2}$ & $\mathrm{Y}_{3}$ \\
\end{tabular}

Sumber: Data diolah, 2018

Berdasar hasil pengolahan data Tabel 5. menujukkan semua indikator memiliki masing-masing Cronbach Alpha bernilai tidak lebih kecil ataupun sama 
dengan 0,60. Dari hasil yang telah diuji, maka dalam kuesioner ini merupakan instrumen yang konsitensinya baik serta layak untuk digunakan.

Tabel 6.

Deskripsi Jawaban Responden (Variabel Brand Image)

\begin{tabular}{|c|c|c|c|c|c|c|c|c|}
\hline \multirow{2}{*}{ No } & \multirow{2}{*}{ Pernyataan } & \multicolumn{5}{|c|}{$\begin{array}{c}\text { Jawaban } \\
(\%)\end{array}$} & \multirow{2}{*}{$\begin{array}{l}\text { rata- } \\
\text { rata }\end{array}$} & \multirow{2}{*}{ Keterangan } \\
\hline & & STS & TS & $\mathrm{CS}$ & $\mathrm{S}$ & $\mathrm{SS}$ & & \\
\hline 1 & $\begin{array}{l}\text { Saya merasa } \\
\text { shuttlecock Pastra } \\
\text { awet saat } \\
\text { digunakan } \\
\text { bermain } \\
\text { bulutangkis (tidak } \\
\text { mudah rusak) }\end{array}$ & - & 1 & 13 & 42 & 40 & 4,21 & Sangat Baik \\
\hline 2 & $\begin{array}{l}\text { Saya merasa } \\
\text { shuttlecock Pastra } \\
\text { merupakan } \\
\text { shuttlecock yang } \\
\text { premium }\end{array}$ & 1 & 3 & 26 & 40 & 30 & 3,95 & Baik \\
\hline 3 & $\begin{array}{l}\text { Shuttlecock Pastra } \\
\text { memiliki kesan } \\
\text { yang baik dibenak } \\
\text { saya }\end{array}$ & - & 1 & 23 & 36 & 40 & 4,15 & Baik \\
\hline 4 & $\begin{array}{l}\text { Menurut saya, } \\
\text { shuttlecock Pastra } \\
\text { adalah merek } \\
\text { shuttlecock yang } \\
\text { mudah saya ingat }\end{array}$ & - & - & 17 & 40 & 43 & 4,26 & Sangat Baik \\
\hline \multicolumn{7}{|c|}{ Rata-rata variabel Brand Image } & 4,14 & Baik \\
\hline
\end{tabular}

Sumber: Data diolah, 2018

Rata-rata nilai keseluruhan persepsi responden untuk variabel brand image adalah sebesar 4,14. Ini menunjukkan kedalam kriteria baik. Jawaban paling tinggi dari responden ditunjukan pada indikator favorable atau dalam pernyataan merek yang mudah diingat dengan rata-rata skor 4,26. Nilai skor rata-rata paling rendah ditunjukan indikator symbolic benefit atau dalam pernyataan merek yang premium dengan rata-rata 3,95 .

Rata-rata dari nilai keseluruhan persepsi responden untuk variabel brand trust adalah 4,15. Ini dapat masuk kedalam kategori baik. Jawaban paling tinggi 
dari responden ditunjukan pada indikator brand reliability atau pada pernyataan shuttlecock Pastra dapat memenuhi kebutuhan untuk bermain bulutangkis dengan rata-rata skor 4,22. Nilai skor rat-rata paling rendah ditunjukan indikator brand characteristic atau pada pernyataan shuttlecock Pastra memiliki reputasi yang baik dengan rata-rata 4,07.

Tabel 7.

Deskripsi Jawaban Responden Terhadap Variabel Brand Trust

\begin{tabular}{|c|c|c|c|c|c|c|c|c|}
\hline \multirow{2}{*}{ Nomor } & \multirow{2}{*}{ Pernyataan } & \multicolumn{5}{|c|}{$\begin{array}{c}\text { Jawaban } \\
(\%)\end{array}$} & \multirow{2}{*}{ rata-rata } & \multirow{2}{*}{ Keterangan } \\
\hline & & STS & TS & $\mathrm{CS}$ & $\mathrm{S}$ & SS & & \\
\hline 1 & $\begin{array}{l}\text { Saya yakin } \\
\text { shuttlecock pastra } \\
\text { dapat memenuhi } \\
\text { kebutuhan saya } \\
\text { untuk bermain } \\
\text { bulutangkis }\end{array}$ & 1 & 1 & 17 & 37 & 44 & 4,22 & Sangat Baik \\
\hline 2 & $\begin{array}{l}\text { Shuttlecock Pastra } \\
\text { memiliki reputasi } \\
\text { yang baik di } \\
\text { benak saya }\end{array}$ & - & 1 & 25 & 40 & 34 & 4,07 & Baik \\
\hline 3 & $\begin{array}{l}\text { Saya merasa suka } \\
\text { menggunakan } \\
\text { shuttlecock Pastra } \\
\text { saat saya bermain } \\
\text { bulutangkis }\end{array}$ & - & 1 & 22 & 36 & 41 & 4,17 & Baik \\
\hline \multicolumn{7}{|c|}{ Rata-rata variabel Brand Trust } & 4,15 & Baik \\
\hline
\end{tabular}

Hasil Tabel 8. menunjukan Rata-rata nilai keseluruhan persepsi responden untuk variabel brand loyalty adalah 4,08. Ini masuk kedalam kategori baik. Jawaban paling tinggi dari responden ditunjukan pada indikator behaviour measures atau pada pernyataan responden terbiasa menggunakan shuttlecock Pastra berulang kali dengan rata-rata skor 4,15. Nilai skor rata-rata paling rendah ditunjukan indikator measuring satisfaction atau pada pernyataan responden merasa puas menggunakan shuttlecock Pastra dengan rata-rata skor 3,98. 
Tabel 8.

Deskripsi Jawaban Responden Terhadap Brand Loyalty

\begin{tabular}{|c|c|c|c|c|c|c|c|c|}
\hline \multirow{2}{*}{ Nomor } & \multirow{2}{*}{ Pernyataan } & \multicolumn{5}{|c|}{$\begin{array}{c}\text { Jawaban } \\
(\%)\end{array}$} & \multirow{2}{*}{ rata-rata } & \multirow[t]{2}{*}{ Keterangan } \\
\hline & & STS & $\mathrm{TS}$ & $\mathrm{CS}$ & $\mathrm{S}$ & SS & & \\
\hline 1 & $\begin{array}{l}\text { Saya terbiasa } \\
\text { menggunakan } \\
\text { berulang kali } \\
\text { shuttlecock } \text { Pastra }\end{array}$ & - & 2 & 21 & 37 & 40 & 4,15 & Sangat Baik \\
\hline 2 & $\begin{array}{l}\text { Saya merasa puas } \\
\text { menggunakan } \\
\text { shuttlecock Pastra }\end{array}$ & - & 1 & 31 & 37 & 31 & 3,98 & Baik \\
\hline 3 & $\begin{array}{l}\text { Saya bersedia } \\
\text { merekomendasikan } \\
\text { shuttlecock Pastra } \\
\text { kepada orang lain }\end{array}$ & - & 2 & 28 & 27 & 43 & 4,11 & Baik \\
\hline \multicolumn{7}{|c|}{ Rata-rata variabel Brand Loyalty } & 4,08 & Baik \\
\hline
\end{tabular}

Sumber: Data diolah, 2018

Tabel 9.

Hasil Uji Normalitas (Persamaan Regresi 1)

\begin{tabular}{lc}
\hline & Unstandardize Residual \\
\hline Kolmogorov-Smirnov & 1,356 \\
Asymp.Sig. (2-tailed) & 0,051 \\
\hline Sumber: Data diolah, 2018 &
\end{tabular}

Nilai dari Kolmogorov-Smirnov adalah 1,356. Nilai Asymp. Sig. (2-tailed) adalah 0,051. Dikarenakan Asymp. Sig.(2-tailed) nilainya lebih dari taraf signifikansi sebesar 5persen atau 0,05 maka model ini berdistribusi secara normal.

Tabel 10.

Hasil Uji Normalitas Persamaan Regresi 2

\begin{tabular}{ll}
\hline & Unstandardize Residual \\
\hline Kolmogorov-Smirnov & 0,776 \\
Asymp.Sig. (2-tailed) & 0,583 \\
\hline
\end{tabular}

Sumber: Data diolah,2018

Nilai dari Asymp.Sig. (2-tailed) adalah 0,583, dimana merupakan nilai yang lebih besar dibandingkan 0,05 sebagai taraf signifikansi, maka model ini berdistibusi normal. 
Tabel 11.

Hasil Uji Multikolinearitas Persamaan Regresi 1

\begin{tabular}{lll}
\hline \multirow{2}{*}{ Model } & \multicolumn{2}{c}{ Colinearity Statistics } \\
\cline { 2 - 3 } & VIF & Tolarance \\
\hline Brand Image & 1,00 & 1,00 \\
\hline Sumber: Data diolah, 2018 & &
\end{tabular}

Sumber: Data diolah, 2018

Tabel 12.

Hasil Uji Multikolinearitas Persamaan Regresi 2

\begin{tabular}{lll}
\hline Model & Colinearity Statistics \\
\hline & VIF & Tolarance \\
\hline Brand Image & 1,997 & 0,501 \\
Brand Trust & 1,997 & 0,501 \\
\hline Sumber: Data diolah, 2018 & &
\end{tabular}

Tidak ada indikasi multikolinearitas antar variabel bebas yang digunakan, ini dibuktikan oleh hasil uji tolerance yang dimana seluruh variable bebas menunjukan nilai tolerance yang tidak lebih kecil atau sama dengan 0,10 . Seluruh variabel bebas menunjukan angka yang tidak lebih besar ataupun sama dengan dari 10 yaitu 1,997 .

Tabel 13.

\begin{tabular}{lc}
\multicolumn{2}{c}{ Hasil Uji Heteroskedastisitas Persamaan Regresi $\mathbf{1}$} \\
\hline Model & Signifikansi \\
\hline Brand Image & 0,140 \\
\hline Sumber: Data diolah, 2018
\end{tabular}

Hasil pengujian pada tabel 13. dan tabel 14. menunjukan bahwa nilai signifikansinya lebih dari $\alpha=0,05$ terhadap absolut residual. Tidak terdapat heterokedastisitas, maka dari itu layak dipergunakan.

Dari hasil Tabel 16, subtruktural 2 dapat dihitung persamaan strukturalnya adalah berikut ini:

$$
\mathrm{Y}=0.414 \mathrm{X}+0.386+\varepsilon_{2}
$$


Menghitung nilai standar error :

$$
\varepsilon_{1}=\sqrt{1-\mathrm{R}_{1}{ }^{2}}
$$

Tabel 14.

Hasil Uji Heteroskedastisitas Persamaan Regresi 2

\begin{tabular}{lc}
\hline Model & Signifik \\
\hline Brand Image & 0,074 \\
Brand Trust & 0,169
\end{tabular}

Sumber: Data diolah, 2018

Tabel 15.

Hasil Analisis Jalur Persamaan Regresi 1

\begin{tabular}{ccccccc}
\hline \multirow{2}{*}{ Model } & \multicolumn{2}{c}{ Unstandardized Coefficients } & $\begin{array}{c}\text { Standardized } \\
\text { Coefficients }\end{array}$ & t & Sig. \\
\cline { 2 - 5 } & B & Std.Error & Beta & & \\
\hline 1 & (Constant) & 1.403 & 0.319 & & 3.273 & 0.001 \\
& Brand Image & 0.751 & 0.076 & 0.707 & 9.885 & 0.000 \\
\hline
\end{tabular}

$\mathrm{R}^{2}$ : $0.499 \quad$ F Statistik : $97.712 \quad$ Sig F : 0,000

Sumber: Data dioah, 2018

Analisis jalur substruktural 1, jadi persamaan strukturalnya adalah berikut ini:

$$
\mathrm{M}=0.707 \mathrm{X}+\varepsilon_{1}
$$

Tabel 16.

\begin{tabular}{|c|c|c|c|c|c|}
\hline \multirow{2}{*}{ Model } & \multicolumn{2}{|c|}{$\begin{array}{c}\text { Unstandardized } \\
\text { Coefficients } \\
\end{array}$} & \multirow{2}{*}{$\begin{array}{c}\begin{array}{c}\text { Standardized } \\
\text { Coefficients }\end{array} \\
\text { Beta }\end{array}$} & \multirow{2}{*}{$\mathbf{t}$} & \multirow{2}{*}{ Sig. } \\
\hline & B & $\begin{array}{c}\text { Std. } \\
\text { Error }\end{array}$ & & & \\
\hline 1 (Constant) & 0.582 & 0.328 & & 1.774 & 0,079 \\
\hline Brand Image & 0.449 & 0.105 & 0.414 & 4.227 & 0,000 \\
\hline Brand Trust & 0.394 & 0.099 & 0.386 & 3.993 & 0,000 \\
\hline
\end{tabular}

Hasil Analisis Jalur Persamaan Regresi 2

Sumber: Data diolah, 2018

$$
\begin{aligned}
& =\sqrt{1-0,499} \\
& =0,501
\end{aligned}
$$




$$
\begin{aligned}
\varepsilon 2 & =\sqrt{1-\mathrm{R}_{2}{ }^{2}} \\
& =\sqrt{1-0,546} \\
& =0,454
\end{aligned}
$$

Koefisien Determinasi total :

$\mathrm{R}^{2} \mathrm{~m} \quad=0,949$

Koefisien determinasi total $=0,949$ dapat diartikan bahwa sebesar $94,9 \%$ variasi brand loyalty dipengaruhi oleh variasi brand image dan brand trust dan $5,10 \%$ dijelaskan variable-variabel yang lain dimana variable tersebut tidak masuk ke dalam model ini.

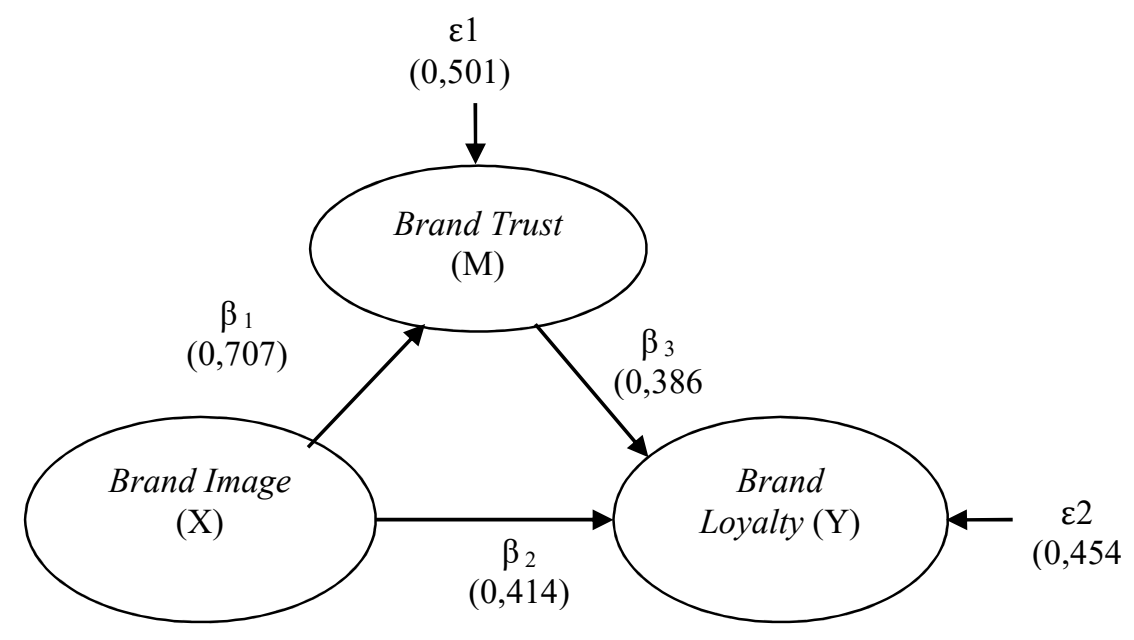

\section{Gambar 2. Validasi Model Diagram Jalur}

Pada Gambar 2. telah digambar diagram jalur, setelah diagram jalur tergambar, selanjutnya menghitung pengaruh langsung, pengaruh total dan juga pengaruh tidak langsugn antar variabel. Tabel 17 dibawah ini akan menggambarkan perhitungan anatar variabel. 
Tabel 17.

Pengaruh Langsung, Pengaruh Tidak Langsung dan Pengaruh Total Brand

\begin{tabular}{cccc}
\multicolumn{4}{c}{ Image $(\mathbf{X})$, Brand Trust $(\mathbf{M})$ dan Brand Loyalty $(\mathbf{Y})$} \\
\hline $\begin{array}{c}\text { Pengaruh } \\
\text { Variabel }\end{array}$ & $\begin{array}{c}\text { Pengaruh } \\
\text { Langsung }\end{array}$ & $\begin{array}{c}\text { Pengaruh Tidak } \\
\text { Langsung Melalui } \\
\text { Brand Trust } \\
(\mathbf{M})=\left(\boldsymbol{\beta}_{\mathbf{1}} \times \boldsymbol{\beta}_{3}\right)\end{array}$ & $\begin{array}{c}\text { Pengaruh } \\
\text { Total }\end{array}$ \\
\hline $\mathrm{X} \rightarrow \mathrm{M}$ & 0,707 & & \\
$\mathrm{X} \rightarrow \mathrm{Y}$ & 0,414 & $(0,707 \times 0,386)=0,272$ & 0,707 \\
$\mathrm{M} \rightarrow \mathrm{Y}$ & 0,386 & & 0,686 \\
\hline
\end{tabular}

Sumber: Data diolah, 2018

Hasil tersebut dapat membuktikan jika brand trust mampu memediasi pengaruh brand image terhadap brand loyalty dimana nilai pengaruh total adalah 0,686 .

Uji sobel dapat dilakukan dengan tahapan berikut:

$$
\begin{aligned}
& \left.S_{a b}=\sqrt{b^{2} \mathrm{Sa}^{2}+\mathrm{a}^{2} \mathrm{Sb}^{2}+\mathrm{Sa}^{2} \mathrm{Sb}^{2}} \ldots \ldots \ldots \ldots \ldots \ldots \ldots \ldots \ldots \ldots \ldots \ldots \ldots \ldots \ldots \ldots\right)^{2}(0,099)^{2} \\
& S_{\mathrm{ab}}=\sqrt{(0,386)^{2}(0,076)^{2}+(0,707)^{2}(0,099)^{2}+(0,076)^{2}} \\
& S_{\mathrm{ab}}=\sqrt{(0,0058)} \\
& S_{\mathrm{ab}}=0,076264
\end{aligned}
$$

Nilai Z :

$$
\begin{aligned}
& z=\frac{a b}{S a b} \ldots \ldots \\
& z=\frac{0,2729}{0,07624} \\
& z=3,57
\end{aligned}
$$

Berdasarkan Hasil kalkulasi nilai $\mathrm{Z}$ hitung sebesar 3,57 > 1,96, maka $\mathrm{H}_{4}$ diterima yang dapat diartikan brand trust dinilai mampu memediasi pengaruh brand image terhadap brand loyalty shuttlecock Pastra. 
Hipotesis1 atau $\mathrm{H}_{1}$, pengaruh brand image terhadap brand trust diterima, dengan demikian brand image berpengaruh positif serta juga signifikan terhadap brand trust shuttlecock Pastra. Hasil tersebut menunjukan bahwa semakin baik brand image shuttlecock Pastra oleh karenanya tingkat brand trust pada produk shuttlecock Pastra akan mengikuti dengan hasil yang sejalan yaiut, meningkat. Penelitian ini didalamnya menemukan hasil serupa dengan penelitian (Alhaddad, 2015; Efendy \& Suryadinata, 2013; Noor, 2014) dimana memperoleh hasil brand image mempunyai pengaruh terhadap brand trust secara positif dan signifikan.

Hipotesis2 atau $\mathrm{H}_{2}$, pengaruh brand image terhadap brand loyalty shuttlecock Pastra diterima, dengan hasil ini artinya adanya pengaruh brand image yang positif dan juga signifikan terhadap brand loyalty shuttlecock Pastra. Hasil ini menunjukan bahwa image yang shuttlecock Pastra yang baik akan meningkatkan loyalitas pada produk shuttlecock Pastra. Temuan ini sama dengan hasil penelitian (Chinamona, 2016; Efendy \& Suryadinata, 2013; Rizan et al., 2012) dimaa medapatkan hasil brand image berpengaruh positif yang juga signifikan terhadap brand loyalty.

Hipotesis3 atau $\mathrm{H}_{3}$, pengaruh brand trust terhadap brand loyalty shuttlecock Pastra diterima, dimana brand trust memiliki pengaruh positif \& signifikan terhadap brand loyalty shuttlecock Pastra. Penelitian dari H3 menunjukan jika semakin baik brand trust shuttlecock Pastra maka tingkat brand loyalty pada shuttlecock Pastra juga semakin tinggi. Hasil didalam penelitian ini mendukung temuan peneliti sebelumnya yaitu (Kabadayi \& Alan, 2012; Kusuma, 2014; Putra 
\& Sulistyawati, 2014) menemukan brand trust mempengaruhi secara positif serta signifikan variabel brand loyalty.

Hipotesis4 atau $\mathrm{H}_{4}$, peran brand trust sebagai pemediasi pengaruh brand image terhadap brand loyalty shuttlecock Pastra diterima, ini artinya adalah brand trust berhasil sebagai variable pemediasi pengaruh brand image terhadap brand loyalty shuttlecock Pastra. Temuan dipenelitian ini sama hasilnya dengan penelitian sebelumnya, oleh (Efendy \& Suryadinata, 2013; Handayani \& Martini, 2015; Rodiques \& Rahanatha, 2018) hasilnya, variabel brand trust berhasil menjadi variabel pemediasi dari pengaruh hubungan citra merek dengan loyalitas konsumen.

\section{SIMPULAN DAN SARAN}

Kesimpulan yang diambil dari temuan tersebut diantaranya adalah brand image secara positif signifikan berpengaruh terhadap brand trust shuttlecock Pastra, oleh karenanya dapat dikatakan dengan semakin baiknya brand image shuttlecock Pastra, akan diikuti dengan brand trust konsumen shuttlecock Pastra yang semakin baik. Brand image memiliki pengaruh yang positif dan juga signifikan terhadap brand loyalty, dengan demikian dapat dikatakan brand image shuttlecock Pastra yang semakin baik akan menimbulkan semakin baiknya brand loyalty yang dimiliki shuttlecock Pastra. Variabel brand trust mempengaruhi secara positif signifikan brand loyalty shuttlecock Pastra, karena ini dikatakan bahwa semakin meningkat brand trust yang dimiliki shuttlecock Pastra maka semakin meingkat pula brand loyalty shuttlecock Pastra. Variabel brand trust berhasil sebagai variabel pemediasi brand image dalam pengaruhnya terhadap 
brand loyalty shuttlecock Pastra. Temuan ini berarti kepercayaan konsumen terhadap suatu merek yang kuat dapat meningkatkan image suatu merek terhadap tingginya loyalitas konsumen terhadap shuttlecock Pastra.

Saran yang dapat diberikan, UD. Pastra harus melakukan pemasaran melalui distribusi langsung ke lapangan-lapangan yang ada di Kota Denpasar serta pemasaran melalui kegiatan promosi (iklan) yang inovatif serta maksimal untuk menjaga brand image dimana kelas sosial yang tinggi dimata pemain bulutangkis di Kota Denpasar. Ud. Pastra harus meningkatkan brand trust atau kepercayaan konsumen terhadap kualitas produknya. Serta untuk mempertahankan pelanggan yang loyal, perusahaan dapat membuat program promosi yang tepat dan agresif, berupa program yang positif dan menguntungkan pelanggan.

Bagi peneliti selanjutnya diharapkan untuk bisa diperluas ruang lingkup penelitiannya dan juga ditambahkan variabel bebas seperti kualitas produk, promosi, perpindahan merek dan variabel variabel bisa mempengaruhi variabel brand loyalty.

\section{REFERENSI}

Alhaddad, A. (2015). A Structural Model Of The Relationship Between Brand Image, Brand Trust and Brand Loyalty. International Journal of Management Reseacrh \& Review, 5(3), 137-144.

Bimal, A., Dhanda, S. K., \& Nagra, S. (2012). Impact of celebrity endorsed advertisements on consumers. Asia Pacific Journal of Marketing \& Management Review, 1(2), 22-33.

Chinamona, R. (2016). Brand Communication, Brand Image and Brand Trust as Antecedents of Brand Loyalty in Gauteng Province of South Africa. African Jurnal of Economic and Management Studies, 7(1), 124-139. https://doi.org/10.1108/AJEMS-03-2013-0031 
Delgado-Ballester, E. (2003). Development and validation of a brand trust scale. International Journal of Market Research, 45(1), 1-28. https://doi.org/10.1088/1751-8113/44/8/085201

Dharmayana, I. M. A., \& Rahanatha, G. B. (2018). Pengaruh Brand Equity, Brand Trust, Brand Preference Dan Kepuasan Konsumen Terhadap Niat Membeli Kembali. E-Jurnal Manajemen Universitas Udayana, 6(4), 2018-2046. Retrieved from https://www.google.co.id/url?sa=t\&rct=j\&q=\&esrc=s\&source=web\&cd=6\& cad $=$ rja\&uact $=8 \&$ ved $=0$ ahUKEwiTg-

mUkY_bAhUKto8KHZA_A9YQFghbMAU\&url=https\%3A\%2F\%2Fojs.un ud.ac.id $\% 2$ Findex.php\%2FManajemen $\% 2$ Farticle $\% 2$ Fview $\% 2 F 28856 \% 2 F 1$ 8230\&usg=AOvVaw1m7UZYau0Vo81avG-rIqwX

Efendy, P., \& Suryadinata, Y. A. (2013). Analisa Pengaruh Brand Image Dan Brand Trust Terhadap Brand Loyalty Di Restoran D ' Cost. Jurnal Hospitality Dan Manajemen Jasa, 3(3), 613-627.

Gecti, F., \& Zengin, H. (2013). The Relationship between Brand Trust, Brand Affect, Attitudinal Loyalty and Behavioral Loyalty: A Field Study towards Sports Shoe Consumers in Turkey. International Journal of Marketing Studies, 5(2), 111-119. https://doi.org/10.1111/j.1365-2400.2004.00391.x

Hadi, P., \& Sumarto. (2010). Pentingnya Brand Loyalty Terhadap Minat Beli Ulang. Jurnal Riset Ekonomi Dan Bisnis, 10(1), 9-18.

Handayani, S., \& Martini, I. (2015). Pengaruh brand image terhadap brand loyality brand trust sebagai variabel mediasi. PPJM (Perkumpulan Pengelola Jurnal Manajemen) Management Dynamic Conference - MADIC National Seminar and Call for Paper, 1, 1-18.

Hayat, K., Ghayyur, M., \& Siddique, A. Z. (2013). The Impact of Consumer Perception Based Advertisement and Celebrity Advertisement on Brand Acceptance: A Case Study of the Peshawar Market. Journal of Managerial Sciences, 7(1), 145-157. from https://acces.bibl.ulaval.ca/login?url=https://search.ebscohost.com/login.aspx ?direct $=$ true $\& \mathrm{db}=$ buh\& $\mathrm{AN}=87064144 \&$ lang $=$ fr\&site $=$ ehost-live

Hidayah, R. T. (2016). PENGARUH BRAND TRUST TERHADAP NIAT KONSUMEN UNTUK MELAKUKAN PEMBELIAN PRODUK ELEKTRONIK PADA SITUS JUAL BELI LAZADA. UNEJ E-Proceeding, 2(4), 122-132.

Kabadayi, E. T., \& Alan, A. K. (2012). BRAND TRUST AND BRAND AFFECT: THEIR STRATEGIS IMPORTANCE ON BRAND LOYALTY. Journal of Global Strategic Management, 6(1), 80-89. https://doi.org/10.20460/JGSM.2012615788 
Kusuma, Y. S. (2014). Pengaruh Brand Experience terhadap Brand Loyalty. Jurnal Manajemen Pemasaran Petra, 2(1), 1-11.

Lau, G. T., \& Lee, S. H. (1999). Consumers' Trust in a Brand and the Link to Brand Loyalty. Journal of Market - Focused Management, 4(4), 341-370. https://doi.org/10.1023/A:1009886520142

Maliyah, S. (2015). Pengaruh Citra Merek, Kepercayaan (Trust) dan Komitmen Terhadap Loyalitas Nasabah Pada PT. Henan Putihrai Asset Management. Jurnal Ilmiah Manajemen Dan Bisnis, 1(1), 9-21.

Neupane, R. (2015). The Effects of Brand Image on Customer Satisfaction and Loyalty Intention in Retail Super Market Chain UK, 2(1), 9-26. https://doi.org/10.3126/ijssm.v2i1.11814

Noor, M. F. (2014). Pengaruh Brand Image Dan Brand Trust. Image, 3(2), $127-$ 140. https://doi.org/10.1006/jfca.2000.0910

Pechyiam, C., \& Jaroenwanit, P. (2014). The Factors Affecting Green Brand Equity of Electronic Products in Thailand. The Macrotheme Review, 3(9), 112.

Putra, B. B. B., \& Sulistyawati, E. (2014). Peran Kepercayaan Merek Dalam Memediasi Pengaruh Kepuasan Pelanggan Terhadap Loyalitas Produk Telepon Pintar Merek Apple di Kota Denpasar. E-Jurnal Manajemen Universitas Udayana, 3(9), 2578-2596.

Rizan, M., Saidani, B., \& Sari, Y. (2012). Pengaruh Brand Image Dan Brand Trust Terhadap Brand Loyalty Teh Botol Sosro. Jurnal Riset Manajemen Sain Indonesia, 3(1), 1-17.

Rodiques, Y., \& Rahanatha, G. B. (2018). PERAN BRAND TRUST MEMEDIASI HUBUNGAN BRAND IMAGE DENGAN BRAND LOYALTY ( Studi Pada Konsumen Iphone di Kota Denpasar ). E-Jurnal Manajemen Universitas Udayana, 7(3), 1310-1338.

Sabunwala, Z. (2013). Impact of Celebrity Brand Endorsements on Brand Image and Product Purchases -a Study for Pune Region of India. International Journal of Research in Business Management, 1(6), 37-42. https://doi.org/10.1021/acs.est.5b00515

Sari, N. P., \& Widowati, R. (2014). Hubungan Antara Kesadaran Merek, Kualitas Persepsian, Kepercayaan Merek dan Minat Beli Produk Hijau. Jurnal Manajemen \& Bisnis, 5(1), 59-79. 
Satyadharma, A. A. (2014). PENGARUH KEPUASAN PELANGGAN TERHADAP KEPERCAYAAN MEREK, LOYALITAS MEREK DAN EKUITAS MEREK MI INSTAN INDOMIE DI SURABAYA, 3(1), 1-19.

Shahroudi, K., \& Naimi, S. S. (2014). The Impact of Brand Image on Customer Satisfaction and Loyalty Intention ( Case Study: Consumer of Hygiene Products ). International Journal of Engineering Innovation \& Research, $3(1)$.

Sibagaring, S. C. H., \& Nursanti, T. D. (2010). Pengaruh Brand Image dan Brand Trsut terhadap Brand Loyalty Pada Pt Bank Sinarmas. Journal The WINNERS, 11(2), 118-129.

Sivesan, S. (2013). Impact of Celebrity Endorsement on Brand Equity in Cosmetic Product. International Journal of Advanced Research in Management and Social Sciences, 2(4), 1-11.

Upamanyu, N. K., \& Mathur, G. (2012). Effect of Brand Trust, Brand Affect and Brand Image On Customer Brand Loyalty and Consumer Brand ExtensIon Attitude In FMCG Sector. Practices and Research in Marketing, 3(2), 1-15.

Venessa, I., \& Arifin, Z. (2017). PENGARUH CITRA MEREK (BRAND IMAGE) DAN HARGA TERHADAP KEPUTUSAN PEMBELIAN KONSUMEN (Survei pada Mahasiswa Program Studi Administrasi Bisnis Fakultas Ilmu Administrasi Universitas Brawijaya Malang Tahun Angkatan 2013/2014 dan 2014/2015 Pengguna Kartu Pra-B. Jurnal Administrasi Bisnis (JAB), 51(1), 44-48.

Zafar, Q., \& Rafique, M. (2010). Impact of Celebrity Advertisement on Customers' Brand Perception and Purchase Intention. Asian Journal of Business and Management Sciences, 1(11), 53-67. https://doi.org/10.5539/ibr.v5n4p55 